\title{
Management of NPA via Capital Adequacy Norms: Its Effect Upon The Profile of Indian Banks and Credit Deposit Ratio
}

\author{
Ramesh Chandra Das ${ }^{\text {aa }}$, Arun Kumar Patra ${ }^{\text {b }}$, Utpal Das ${ }^{\mathrm{c}}$ \\ ${ }^{\mathrm{a}}$ Associate Professor in Economics, Katwa College, WB, India \\ ${ }^{\mathrm{b}}$ Associate Professor in Commerce, Katwa College, WB, India \\ ${ }^{\mathrm{c}}$ Assistant Professor in Commerce, Katwa College, WB, India
}

\begin{abstract}
The reform agenda in the financial as well as banking sector in the Indian economy was not only in the target of achieving profitable banking business but also to reduce the magnitude of banking funds locked in the bad debt account so that, among others, the real delivery of credit (the credit-deposit ratio) rises in overall fronts. The Narasimham Committee Report in respect of reducing magnitude of non- performing assets has been framed in line with the Basel Norm regarding the asset quality of the banks where capital adequacy ratio has been fixed for different banks to achieve within different time periods. The present study, under such a back ground, has been structured to examine the profile of all Scheduled Commercial Banks in all ranges of CRAR over time in aggregate and bank group specific and to measure degree of correlation of NPA-Deposit ratio with CRAR trends and CreditDeposit Ratio in all ranges of CRAR and their significance levels for the time period 1995-96 to 2009-2010. It has been observed that there has been variation across banks in following the guidelines of the reform committee. SBI group and foreign banks have been performing well in this respect. There has been rising trend of the proportions of banks in the above 10 per cent range of CRAR. The NPA/D ratio and C-D ratio have been observed to be positively and negatively correlated respectively for the first three ranges of CRAR and reverse in the above 10 per cent range. The correlation between the NPA/D ratio and C-D ratio is negative and significant.
\end{abstract}

Key Words: NPA, Capital adequacy ratio, CRAR, Credit-Deposit ratio, NPA-Deposit ratio

JEL classification: $\mathrm{M} 13$

\section{(C) 2014 Published by SSBFNET}

\section{Introduction}

Indian financial system has experienced different phases of developments in its history of independence that are ranging from the state control to relatively more market based. The first four decades of economic development was mostly the state controlled economy but after that the country entered into new economic dimension in the name of economic liberalization that opened up the possibilities of all sectors of the economy to the foreign partners that was as a part of the correction of the past gloomy pictures along with the agreement with the international organizations. The financial system of the country has several wings out of which the commercial banking sector occupies a vast area.

\footnotetext{
a All future correspondences should be made at Dr. Ramesh Chandra Das, Katwa College Quarters, Qtr. No. 1, Katwa, Burdwan, West Bengal, India, Pin Code-713130,
} 
Indian financial system, particularly the banking system had experienced a string of crises in terms of bank failures resulting into slow growth of this sector during the late eighties or early nineties.

The present study, under such a back ground, has been structured to examine the profile of all Scheduled Commercial Banks in all ranges of CRAR over time in aggregate and bank group specific and to measure degree of correlation of NPA-Deposit ratio with CRAR trends and Credit-Deposit Ratio in all ranges of CRAR and their significance levels for the time period $1995-96$ to $2009-2010$.

\section{Literature Review}

Indian economy has been brought into the phase of liberalization in the period of 1991-92 with the motive of making the economy control free in one hand and solving the low growth, low employment like crisis on the other hand. Results of some of the research works have proved a phenomenal rise in the growth rate of the aggregate as well as sectoral outputs. Besides there are signs of improvements in the magnitudes of other macroeconomic variables like inflation rate, current account and fiscal deficits, foreign exchange reserves, etc. Reforms in the banking sector possess a giant share in the entire area of the reform programmes. Banking sector reform was done on the expectation of allocation of more commercial banks' credit in particular relative to their levels of deposits to the existing real sectors vis-à-vis reducing operating costs of banks and statutory reserve and cash reserve ratios.

Special attention was put upon reduction of a large fund in the head of bad debt which is popularly known as the nonperforming assets (NPA) so that the productive real sectors are entitled to get more bank credit in one hand and profitability of banks rises. Not only it will improve the health of the banking institutions, it will also lead to influence the real sectors' output growth through channelization of savings money into investment money as there is linkage between financial sector and real sector (King \& Levine, 1993, Goldsmith, 1969). Empirical researches in this area have shown that there are phenomenal growth of levels of credits and deposits of the commercial banks of the major states in India after the reform process initiated compared to the pre-reform phase but the level of credit-deposit (C-D) ratios have unquestionably gone down in the first few years of the reform era and then tend to rise (Das \& Maiti, 1998, Das et al, 1998, Misra, 2003, Das \& Ray, 2009). At the same time there are rising trends of commercial banks' intention of making their funds to be invested in the government and other approved securities other than investing in the real sectors in spite of significant margin of fall in the non-performing assets (NPA) of the banks. This alternatively means that the magnitude of funds locked in the SLR and CRR clauses have tend to rise instead of falling as what was recommended by the reform committee (Das op cit and Marjit et al, 2003). However, there is falling trend of C-D ratio at the all India level up to the year 1999 and then it started rising. In over all period of reform there has been rising trend of C-D ratio at the all India level. Different regulatory measures in improving the asset quality (or to reduce magnitude of NPA) and to release more deposit funds to the real sector investment from security investments were considerably taken.

Quality of banking asset or capital has been planned to be assessed by the capital adequacy norms or the capital to risk weighted asset ratio (CRAR) under different targets as stipulated by Basel I and II Accords in different time periods 
for all types of banks in international levels. Indian banking system has also allowed its banking sector to follow such a banking supervision that is accepted worldwide. There has been financial cointegration all around the world as far as the banking supervision is concerned.

Traditionally the banking institutions were entrusted with the collection of money as deposit through various deposits mobilizing activities and lending of this fund to the productive units of the economy depends mostly upon the market rule under a small quantity of transactions. The lending was mostly protected by various collaterals and therefore the concept of bad debt or non-performance of the asset did not arise in that sense. But as the size of the financial market tended to rise there arose the problem of $\mathrm{X}$-inefficiency in management in the entire banking network. From the Theory of Industrial Organization (Tirole, 1988) we know that there is usually a direct relationship between the rise in scale of operation and $\mathrm{X}$-inefficiency in management leading to rise in overall cost of production which again leads to reduction of competitiveness and so exodus of firms from the industry appears as the ultimate outcome.

The cost of inefficiency in the banking industry arises in the form of bad loans, bad debts or non-performing assets etc, among others. The severity of the NPA problem in the Indian economy was first realized in the early nineties. After the recommendation of the Narasimham Committee (1991 \& 1998) on the financial system in general and the banking sector in particular some steps have been seriously proposed to reduce the magnitude of NPA problems. The RBI, in compliance with the international practices and Narasimham Committee Report circulated some guidelines regarding the NPA, which was to be strictly followed from the year 1992-93. According to RBI Reports on Trends and Progress of Banking in India a term loan account is to be framed under the purview of non-performance if interest or loan installments remain overdue for a period of four quarters during the $31^{\text {st }}$ March 1993, three quarters during the year ending of $31^{\text {st }}$ March, 1994, more than 180 days during the $31^{\text {st }}$ March 1995-2003 and more than 90 days during $31^{\text {st }}$ March 2004 onwards. A cash credit or over draft account, that is a running account, is to be treated as bad debt if it becomes out of order for a period of four quarters during the $31^{\text {st }}$ March 1993, three quarters during the $31^{\text {st }}$ March 1994 and two quarters during the $31^{\text {st }}$ March, 1995-2003. The norm is similar to the bills purchased accounts. According to the circular of RBI, gross NPA covers the bad debts generating from all outstanding loans and advances including advances for which refinances have been received but excluding the re-discounted bills and advances written off at the head office level.

The chief reason behind the accumulation of NPA is the working of the over-regulated real and financial sector of the economy. There may be the cause of macroeconomic recession backed by infrastructural bottlenecks that provoke the entrepreneurs to divert their funds from the originally proposed use. Diversion of funds mostly for business expansion in terms of diversification or modernization from its original purpose can also be the cause of the formation of NPAs. Finally there are the unavoidable factors for the appearance of the NPAs are government policies, strategic behaviour of the borrower in the form of willful default, fraud, misappropriation and deficiencies on the part of the bank officials in sanctioning the borrowers, co-activated by the delay in the legal system. According to the primary study by Jain (2007) on a number of credit officers of several commercial banks operating in India it is observed that 64.29 per cent out of the 56 respondents blame the existing legal system of the country as the prime cause of generating such a huge 
amount of NPAs. The credit officers opine that the introduction of SARFAESI (The Securitisation and Reconstruction of Financial Assets and Enforcement of Security Interest) Act, 2002 will change the scenario drastically because by the help of this Act the bankers will have the right to seize the security of the borrower without waiting for ten to fifteen years for legal judgment. According to the view of Muniappam (2002) the problem of NPA is related to several internal factors like fund diversion for taking up new projects or assisting associate concerns, inefficient managements and external factors like the overall economic recession, power shortage, price escalation and natural calamities. There are some studies in the related area where it is proposed that the accumulation of bad assets by the banking system is the result of unconcerned and lazy lending policy of the banks (Reddy, 2004, Mohan, 2003, McGoven, 1993). The shirking behavior on the part of the defaulter is a rational behavior and that takes into account the expected value of the cost and benefits of such a decision to be a defaulter of bank loans. It has been explored by Rajeev and Mahesh (2010) that the reduction of NPA magnitude in Indian public sector banks by self monitoring and recognition of the problem. It also points out that the self help type group behavior has helped in recovering the bad loans in the Indian public sector banks and hence they recommend the self help group model to apply not only to take part as financial inclusion but also to grow consciousness among the loan recipients to repay the amount.

The problem of NPA is worldwide. Almost all countries in the world have been suffering from the problem in different magnitudes. The well-known South-East Asian crisis in the late 1990's was due to the co-existence of a similar kind of problems. As the Asian miracle welcomed high magnitude of capital inflows, the lack of a developed and non-insulatory financial and capital market had led the governments to form a healthy credit environment to promote industrial growth without looking much at the collaterals against the delivered credit. The ultimate effect was the accumulation of huge share of loan as bad debt, which occupies a giant share in the respective countries' GDP. Thailand, with a 45 per cent share of NPA out of the total delivered credit, has a highest figure of 70 per cent of NPA as proportion of GDP followed by Indonesia (53 per cent), Malaysia (42 per cent) and Korea (35 per cent). Japan, on the other hand, has a GDP share of 28 per cent locked under NPA head. Therefore, the management of NPA is seriously needed to assure the well functioning of the financial markets. The Narasimham Committee has recommended several accounting norms for treating an asset to be non-performing. The norms, as the report suggested, are commonly known as the Prudential Norms and the Capital Adequacy Norms.

The Prudential Norms contain the following heads: income recognition, asset classification and provisioning. Banks are to classify their loan accounts as income performing and non-performing. If the asset is performing then the interest income will be recognized on the accrual basis but for an asset to be non-performing, its income will be recognized on the cash basis. With regard to the asset classification, a non-performing asset is classified into three categories, namely, substandard, doubtful and loss asset. All the government (either central or state) securities are usually treated as standard assets by the banking and financial institutions. A credit facility falls under the substandard category if its classification as NPA holds for not more than two years. Provisioning is done after classifying loan assets in different categories, namely, standard, sub-standard, doubtful and loss assets. As per the category of a standard asset, presently no provisioning is required under the prudential norms. Regarding sub-standard assets the 
amount required for provisioning is 10 per cent of the total outstanding amount 31.03.2000. The provisioning under the doubtful assets is two-fold: for the secured portion of the asset, the provisioning will vary from 10 per cent to 50 per cent depending upon the period for which the asset has been categorized as doubtful and 100 per cent for the unsecured outstanding advances.

Another important organ of the prudential norm for the SCBs and development banking institutions which is relevant to our study is the Capital Adequacy Norms that was established by the Basel Committee I and II (1988 \& 2004) on the Banking Supervisions respectively in the year 1988 and 2004 (Sarma \& Nikaido). Capital Adequacy Ratio (CAR), also known as Capital to Risk (Weighted) Assets Ratio (CRAR), is a ratio of a bank's capital to its risk. National regulators track a bank's CAR to ensure that it can absorb a reasonable amount of loss and complies with statutory Capital requirements. Capital requirement (also known as Regulatory capital or Capital adequacy) is the amount of capital a bank or other financial institution has to hold as required by its financial regulator. This is in the context of fractional reserve banking and is usually expressed as a capital adequacy ratio of liquid assets that must be held compared to the amount of money that is lent out. These requirements are put into place to ensure that these institutions are not participating or holding investments that increase the risk of default and that they have enough capital to sustain operating losses while still honoring withdrawals.

\section{Research and Methodology}

\subsection{Objective of the Study}

The present study has tried to concentrate upon the management of NPA by means of capital adequacy norms in case of Indian banks under the head of two objectives. First, it tries to study the profile of different scheduled commercial banks (SCBs) in different ranges of capital adequacy norms in different time periods and to compare their relative positions. Second, is to study whether there has been a significant correlation of CRAR trends with NPA-Deposit ratio and credit-deposit ratio.

\subsection{Plan of the Study}

The entire study has been arranged in the following manner.

Section 4 points out the data source and methodology. Section 5 covers the discussion of concepts and management of NPA along with the computation of CRAR. Section 6 analyses the first objective and Section 7 analyses the second objective. Section 8 concludes the entire study.

\subsection{Data Source}

Since the reform process has been initiated during the early nineties and to get its impact upon the economy it takes a transition phase. We, thus, considered the period 1995-96 to 2009-10 as the period of study and the data for all the variables are considered for all India level only. We use only the data of Scheduled Commercial Banks (SCBs) published in Basic Statistical Returns of Reserve Bank of India for different years. Besides, the publications of different research articles have been other sources of information. 
Primarily the graphical technique has been followed to present the over view of the data. Different statistical tools like mean, standard deviation and coefficients of variations have been applied for quantification of basic statistical measures. The correlation among different variables has been computed by the following formula-

$\mathrm{r}=\operatorname{Cov}(\mathrm{x}, \mathrm{y}) / \mathrm{S} \cdot \mathrm{D}_{\mathrm{x}} \cdot \mathrm{S} \cdot \mathrm{D}_{\mathrm{y}}=\left[\sum \mathrm{xy}-\sum(\mathrm{x} / \mathrm{n}) \cdot \sum(\mathrm{y} / \mathrm{n})\right] /\left[\sum \mathrm{x}^{2}-\left(\sum \mathrm{x} / \mathrm{n}\right)^{2}\right]\left[\sum \mathrm{y}^{2}-\left(\sum \mathrm{y} / \mathrm{n}\right)^{2}\right]$

This is known as Pearson's Product Moment Correlation. The significance of $\mathrm{r}$ has been tested by the student's t ratio which is

$t=r \sqrt{ }(n-2) / \sqrt{ }\left(1-r^{2}\right)$

for the Null Hypothesis $\mathrm{H}_{0}: \rho=0$ against the Alternative Hypothesis $\mathrm{H}_{1}: \rho \neq 0$ for the degrees of freedom (df) $n-2$ which is $15-2=13$ in our study.

\subsection{Formula of CRAR}

Capital adequacy ratios (CARs) are a measure of the amount of a bank's core capital expressed as a percentage of its risk-weighted asset. The core capital is expressed as the sum of Tier 1 and Tier 2 capital. Tier 1 capital is the difference between the sums of paid up capital (PUC), statutory reserves (SR) and disclosed free reserves (DFR) and the sum of equity investments in subsidiary (EIS), intangible assets (IA) and current and broad forward losses (BFL). On the other hand, Tier 2 capital is the sum of undisclosed Reserves (UR), General Loss reserves (GLR) and hybrid debt capital instruments and subordinated debts (HDCSD). On the basis of the capital definitions, Capital adequacy ratio is defined as

$C A R=C R A R=($ Tier 1 capital + Tier 2 capital $) /$ Risk weighted assets

where Risk can either be weighted assets (w) or the respective national regulator's minimum total capital requirement. If using risk weighted assets, $\mathrm{w}$, it is reoriented as

$C R A R=(T 1+T 2) / w=[(P U C+S R+D F R-E I S-I A-B F L)+(U R+G L R+H D C S D)] / w$

An asset with zero risk is said to be a standard asset and a hundred per cent risky asset is nearly a loss asset. A higher capital adequacy ratio implies that the health of the bank's financial position is sound while a lower capital adequacy ratio implies the poor health of the financial position of the bank. The percent threshold varies from bank to bank that is set by the national banking regulator of different countries. In India, RBI guideline has been framed in line with the recommendations of the Narasimham Committee Report and the Basel Accords on Banking Supervisions. The Committee recommended that a bank's regulatory capital would be at least 8 per cent of its risk-weighted assets where the assets are risk-weighted according to their credit risk. In the Indian economy the Basel norm has been adopted in April 1992 for the scheduled commercial banks and its implementation was spread over the next three years. It was stipulated that the scheduled commercial banks should achieve the 4 per cent CRAR by 1993 and 8 per cent by 1996 whereas the foreign banks operating in Indian soil should achieve the 8 per cent target by March 1993. Narasimham Committee on the banking sector reforms had recommended a 10 per cent CRAR by the year 2002 (Jain, op cit). The capital adequacy ratio of India is very much close to the position of Asian giants like Korea, Malaysia and Singapore 
but better than China (with less than 8 per cent) and Japan (with less than 9 per cent) (Sarma \& Nikaido, op cit). Foreign banks operating in India have a highest rate of CRAR followed by Indian Public Sector Banks, Old Private Sector Banks and New Private Sector Banks for the period.

\subsection{Profiles of SCBs in Different Ranges of CRAR}

After the publication of the RBI guideline regarding maintenance of CRAR of different banks to protect their financial health, different scheduled commercial banks have tried to keep their CRAR levels that are presented in Table 1. Total number of SCBs has been divided into SBI Group, Nationalized Banks, Old Private Sector Banks, New Private Sector Banks and Foreign Banks. Although the target of 4 per cent of CRAR is to be maintained by the banks by the year 1993 there are certain numbers of banks even up to the period 2006-07 that could not meet the guideline.

There are no banks of SBI Group, New Private Banks and Foreign banks that failed to meet the target. The poorly performing banks in this respect are the Nationalized Banks and Old Private Banks. Out of 8 such banks with less than 4 per cent of CRAR there are 5 nationalized banks and 3 old private banks. The situation does not change for the range of CRAR of 4-9 per cent. But there are falling trends in the number of banks in both of the ranges of CRAR. Most of the banks have followed the CRAR range of 9-10 per cent and over 10 per cent target. It is clear from the table.

The proper proportion of banks in different ranges of CRAR levels has been computed to find out the accountability and adaptability of different commercial banks in India that has been pointed out in Figure 1. It is observed that the proportions of banks in all ranges of CRAR except the ratio above 10 per cent have followed diminishing trends over time. There has been transformation of banks from the low levels of CRAR ranges towards the upper levels of CRAR which is a good sign to the Indian banking system. The trend of the 9-10 per cent CRAR has steeply fallen and converges towards the value zero and the proportion of banks in the above 10 per cent range has got upward trend.

The trends are seemed to be opposite to each other meaning the fact that the banks have converted their asset positions into upper level of CRAR as addressed by the Basel accord and the Narasimham Committee Report. Studying the interbank positions it is observed from Table 2 and 3 that the weightage of nationalized banks and foreign banks are higher. 
Table 1: Number of banks in different ranges of CRAR with their variations

\begin{tabular}{|l|l|l|l|l|l|l|l|}
\hline Year & $\underline{\text { Below 4\% }}$ & $\underline{\mathbf{4 - 9} \%}$ & $\underline{\mathbf{9 - 1 0} \%}$ & $\underline{\text { Above 10\% }}$ & $\underline{\text { Banks in all Ranges }}$ & $\underline{\underline{\text { S.D }}}$ & $\underline{\underline{\text { C.V }}}$ \\
\hline $1995-96$ & 8 & 9 & 33 & 42 & 92 & 17.146 & 74.55 \\
\hline $1996-97$ & 5 & 1 & 30 & 64 & 100 & 28.994 & 116 \\
\hline $1997-98$ & 3 & 2 & 27 & 71 & 103 & 32.305 & 125.5 \\
\hline $1998-99$ & 4 & 2 & 23 & 76 & 105 & 34.49 & 131.4 \\
\hline $1999-00$ & 3 & 2 & 11 & 84 & 100 & 39.539 & 158.2 \\
\hline $2000-01$ & 3 & 2 & 11 & 84 & 100 & 39.539 & 158.2 \\
\hline $2001-02$ & 1 & 2 & 7 & 81 & 91 & 38.922 & 171.1 \\
\hline $2002-03$ & 2 & 0 & 3 & 88 & 93 & 43.185 & 185.7 \\
\hline $2003-04$ & 1 & 1 & 1 & 87 & 90 & 43 & 191.1 \\
\hline $2004-05$ & 1 & 1 & 8 & 78 & 88 & 37.479 & 170.4 \\
\hline $2005-06$ & 3 & 0 & 4 & 78 & 85 & 37.871 & 178.2 \\
\hline $2006-07$ & 1 & 0 & 2 & 79 & 82 & 39.009 & 190.3 \\
\hline $2007-08$ & 0 & 0 & 2 & 77 & 79 & 38.178 & 193.3 \\
\hline $2008-09$ & 0 & 0 & 0 & 80 & 80 & 40 & 200 \\
\hline $2009-10$ & 0 & 1 & 0 & 80 & 81 & 39.836 & 196.7 \\
\hline
\end{tabular}

Source: Reserve Bank of India Handbook on Indian Economy various issues

Note: Figures computed by the authors

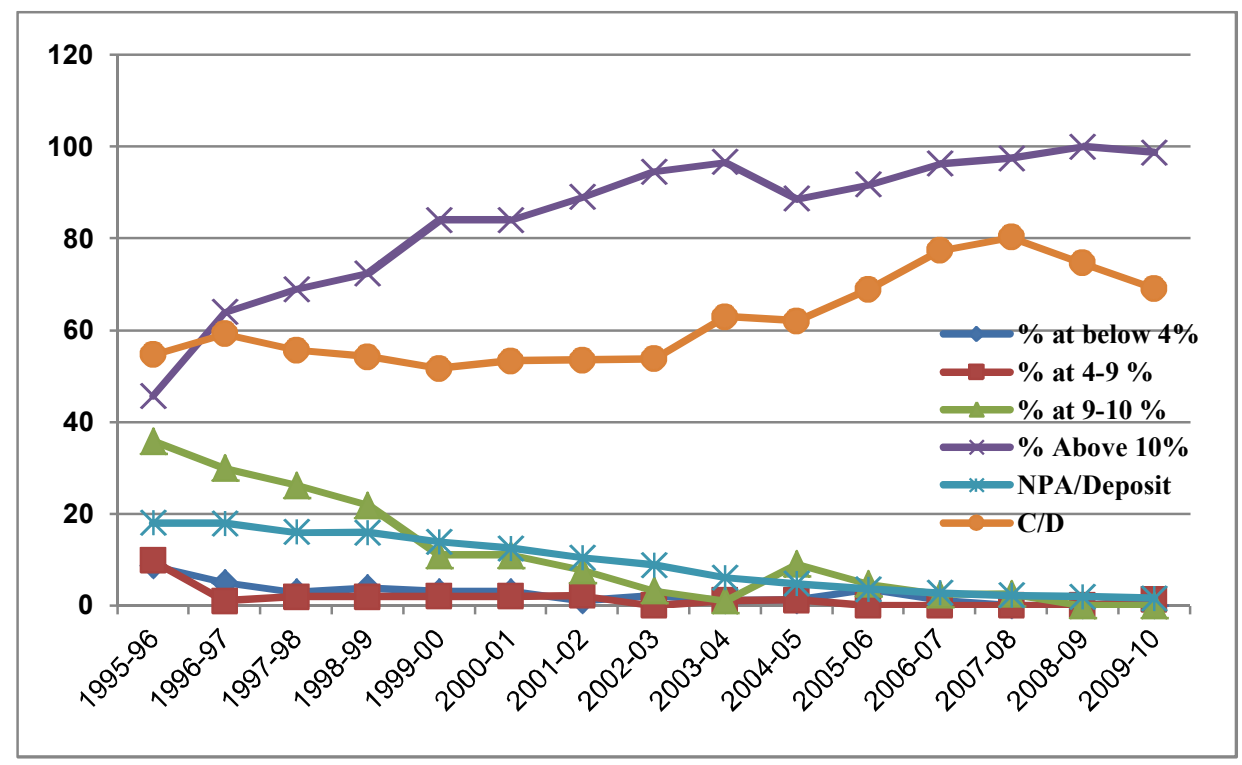

Figure 1. Proportion of Banks in different ranges of CRAR target

Another point to note that there is rising variations of the number of banks across different levels of CRAR over time that shows inequitable positions of the banks regarding the improvements of the asset positions of the banks (Table 1 and Figure 2). The source of such rising variations is the entry of banks into the upper levels of CRAR. This is a good 
sign of the banking industry since most of the banks have tried maintaining their quality of capital that not only improves the profit levels but also reduces the risk of lending assets. But from the point of view of the economy as a whole, such a rising trend in C.V or S.D will help in extra credit delivery and as a result of that the C-D ratio will rise (Figure 1). The resultant effect of the shifting of commercial banks in the management of bad debts by means of capital adequacy norms possibly is the falling trend of NPA-Deposit ratio and rising trend of C-D ratio.

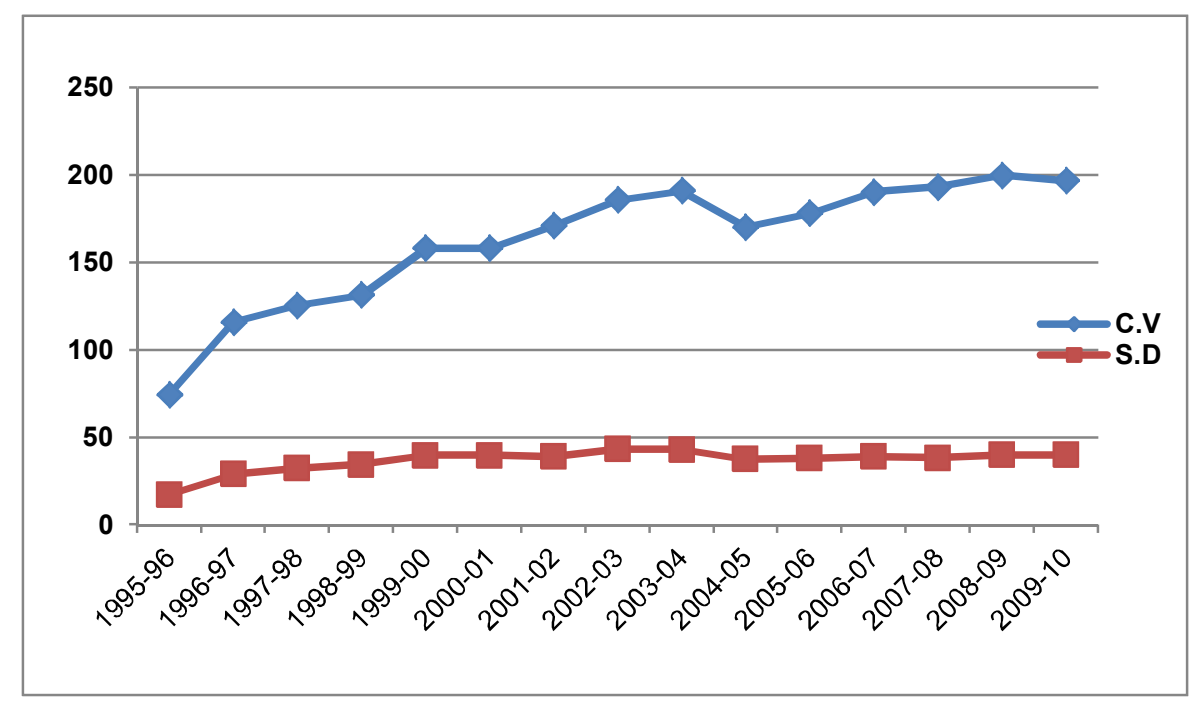

Figure 2. Variations of the number of banks in different ranges of CRAR over time

Table 2: Profiles of SBI Group and Nationalized Banks

\begin{tabular}{|c|c|c|c|c|c|c|c|c|c|}
\hline & State $F$ & $\operatorname{lnk}$ G & & & & Nationalis & Banks & & \\
\hline Year & $\begin{array}{l}\text { Below } \\
\underline{4 \%} \\
\end{array}$ & $\frac{4-9}{\%}$ & $\frac{9-10}{\%}$ & $\frac{\text { Above }}{10 \%}$ & Year & Below 4\% & $\frac{4-9}{\%}$ & $9-10 \%$ & $\frac{\text { Above }}{10 \%}$ \\
\hline $1995-96$ & 0 & 0 & 6 & 2 & $1995-96$ & 5 & 3 & 7 & 4 \\
\hline 1996-97 & 0 & 0 & 3 & 5 & 1996-97 & 2 & 0 & 6 & 11 \\
\hline $1997-98$ & 0 & 0 & 1 & 7 & $1997-98$ & 1 & 0 & 6 & 12 \\
\hline 1998-99 & 0 & 0 & 0 & 8 & 1998-99 & 1 & 0 & 4 & 14 \\
\hline 1999-00 & 0 & 0 & 0 & 8 & 1999-00 & 1 & 0 & 4 & 14 \\
\hline $2000-01$ & 0 & 0 & 0 & 8 & $2000-01$ & 1 & 1 & 2 & 15 \\
\hline 2001-02 & 0 & 0 & 0 & 8 & 2001-02 & 1 & 1 & 2 & 15 \\
\hline 2002-03 & 0 & 0 & 0 & 8 & 2002-03 & 0 & 0 & 1 & 18 \\
\hline 2003-04 & 0 & 0 & 0 & 8 & 2003-04 & 0 & 0 & 1 & 18 \\
\hline 2004-05 & 0 & 0 & 0 & 8 & 2004-05 & 0 & 0 & 2 & 18 \\
\hline $2005-06$ & 0 & 0 & 0 & 8 & $2005-06$ & 0 & 0 & 0 & 19 \\
\hline 2006-07 & 0 & 0 & 0 & 8 & 2006-07 & 0 & 0 & 0 & 20 \\
\hline $2007-08$ & 0 & 0 & 0 & 8 & $2007-08$ & 0 & 0 & 0 & 20 \\
\hline 2008-09 & 0 & 0 & 0 & 7 & 2008-09 & 0 & 0 & 0 & 20 \\
\hline $2009-10$ & 0 & 0 & 0 & 7 & 2009-10 & 0 & 0 & 0 & 20 \\
\hline
\end{tabular}


Table 3: Profiles of Old and New Private and Foreign Banks

\begin{tabular}{|c|c|c|c|c|c|c|c|c|c|c|c|c|}
\hline \multirow[b]{2}{*}{ Year } & \multicolumn{4}{|c|}{ Old Private Sector Banks } & \multicolumn{4}{|c|}{ New Private Sector Banks } & \multicolumn{4}{|c|}{ Foreign Banks in India } \\
\hline & $\leq$ & $4-9 \%$ & $9-10 \%$ & $\begin{array}{l}\geq \\
10 \%\end{array}$ & $\begin{array}{l}\leq \% \\
4 \%\end{array}$ & $\frac{4-9}{\%}$ & $\frac{9-10}{\%}$ & $\begin{array}{l}\geq \\
10 \%\end{array}$ & $<4 \%$ & $\frac{4-9}{\%}$ & $\frac{9-10}{\%}$ & $\begin{array}{l}\geq \\
10 \%\end{array}$ \\
\hline $1995-96$ & 3 & 3 & 7 & 12 & 0 & 0 & 1 & 8 & 0 & 3 & 12 & 16 \\
\hline 1996-97 & 3 & 1 & 8 & 13 & 0 & 0 & 0 & 9 & 0 & 0 & 13 & 26 \\
\hline $1997-98$ & 2 & 2 & 6 & 15 & 0 & 0 & 2 & 7 & 0 & 0 & 12 & 30 \\
\hline 1998-99 & 2 & 2 & 3 & 18 & 0 & 0 & 2 & 7 & 1 & 0 & 14 & 29 \\
\hline 1999-00 & 2 & 2 & 2 & 18 & 0 & 0 & 1 & 7 & 0 & 0 & 5 & 37 \\
\hline 2000-01 & 2 & 1 & 4 & 16 & 0 & 0 & 1 & 7 & 0 & 0 & 4 & 38 \\
\hline 2001-02 & 0 & 0 & 2 & 19 & 0 & 1 & 1 & 6 & 0 & 0 & 2 & 33 \\
\hline 2002-03 & 0 & 0 & 1 & 20 & 2 & 0 & 1 & 6 & 0 & 0 & 0 & 36 \\
\hline 2003-04 & 1 & 1 & 0 & 8 & 1 & 1 & 0 & 8 & 0 & 0 & 0 & 33 \\
\hline 2004-05 & 0 & 0 & 2 & 7 & 0 & 0 & 2 & 7 & 0 & 0 & 1 & 30 \\
\hline 2005-06 & 3 & 0 & 1 & 16 & 0 & 0 & 1 & 7 & 0 & 0 & 2 & 27 \\
\hline 2006-07 & 1 & 0 & 2 & 14 & 0 & 0 & 0 & 8 & 0 & 0 & 0 & 29 \\
\hline 2007-08 & 0 & 0 & 1 & 14 & 0 & 0 & 0 & 8 & 0 & 0 & 1 & 27 \\
\hline 2008-09 & 0 & 0 & 0 & 15 & 0 & 0 & 0 & 7 & 0 & 0 & 0 & 31 \\
\hline 2009-10 & 1 & 0 & 0 & 14 & 0 & 0 & 0 & 7 & 0 & 0 & 0 & 32 \\
\hline
\end{tabular}

The positions of different banks have also been a concern to have a unique qualitative performance of the financial system. It is observed from Table 2 and 3 and Figure 3 and 4 that SBI group has maintained a sustained level of CRAR over time. All the banks in this group have maintained above 10 per cent CRAR range from 1998-99 that protects the bank from vulnerability. Foreign banks also present the satisfactory asset positions. The worst performance in this regard has been for the old private and nationalized banks.

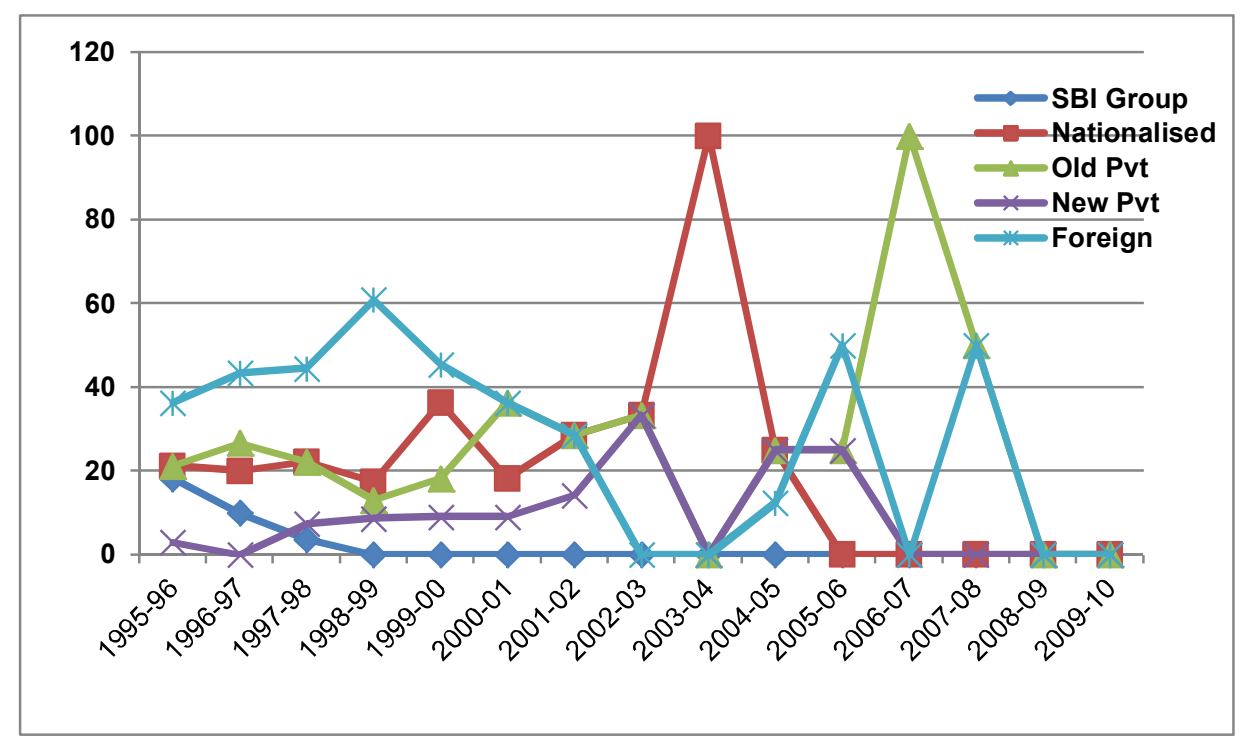

Figure 3. Proportions of different banks in 9-10 per cent CRAR 


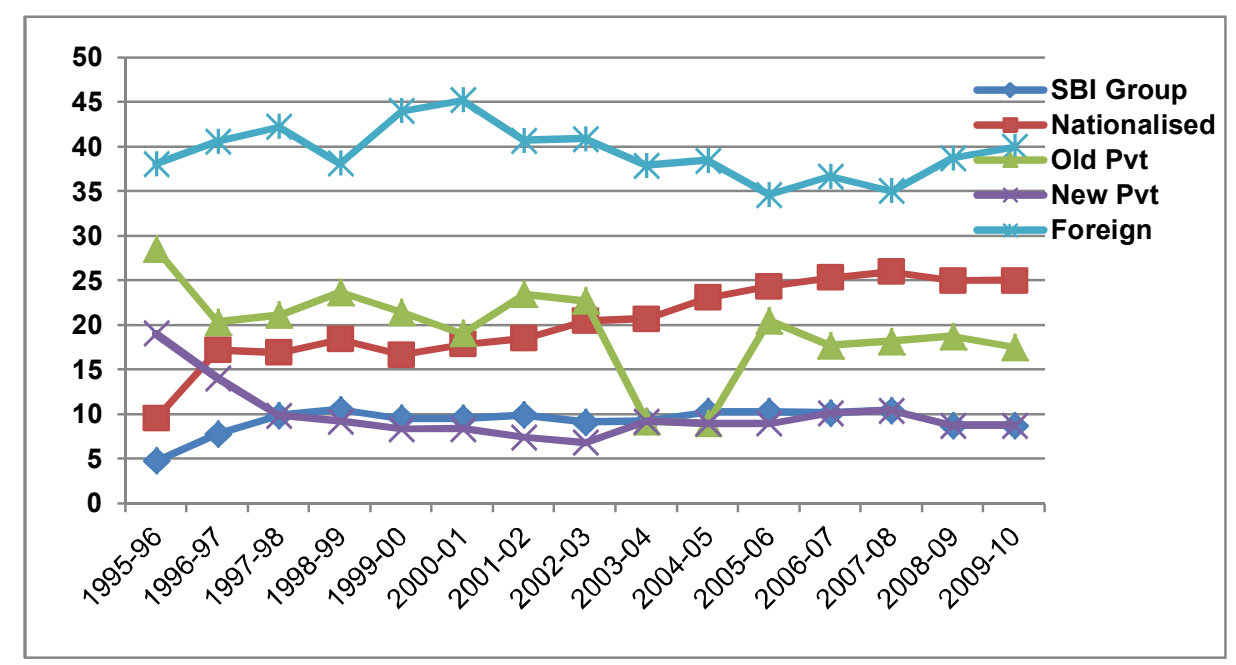

Figure 4. Proportions of different banks above 10 per cent CRAR

With respect to the share of different banks in the above 10 per cent range it is observed that the nationalized banks have improved much compared to the other banks. The proportions of banks in foregn origin have been falling, although it is still holding large number of banks. It is, therefore, inferred from the above analysis that the SBI group and the foreign banks have maintained the guidelines of the Narasimham Committee and the Basel Accord time to time compared to the other categories of banks. The nationalized banks, though late, has tried to overcome the problem of managing their own assets.

\section{Correlation Analysis}

One of the major objectives of the financial reform agenda was to securitization of the banking capitals by means of capital adequacy norms so that the magnitudes of NPA as a proportion to total deposit (NPA/D) will fall and as a result of that the overall C-D ratio will rise. On this ground our present study deserves attention. Usually there should be positive correlations between the NPA/D levels with the proportions of banks in the different ranges of CRAR levels along with the C-D ratio. Also the same can be applicable when the correlation is measured for C-D ratio with the proportions of banks in different ranges of CRAR levels.

Table 4 highlights the same aspect with respect to the aggregate SCBs which is the club of all banks in all ranges of CRAR. The significance levels of the computed correlation coefficients are also tested. 
Table 4: Correlation coefficients

\begin{tabular}{|l|l|l|l|l|l|l|}
\hline & $\underline{\text { \% at below 4\% }}$ & $\underline{\text { \% at 4-9 \% }}$ & $\underline{\text { \% at 9-10\% }}$ & $\underline{\text { \% Above 10\% }}$ & $\underline{\text { NPA/Deposit }}$ & $\underline{\text { C-D Ratio }}$ \\
\hline Correlation(NPA/D) & 0.7870 & 0.5911 & 0.8936 & -0.8796 & 1 & -0.8102 \\
\hline$\underline{\text { t ratio }>>}$ & $(4.60)$ & $(2.64)$ & $(7.17)$ & $(-6.66)$ & & $(-4.98)$ \\
\hline Correlation(C/D) $>>$ & -0.5404 & -0.4595 & -0.5536 & 0.5672 & -0.8102 & 1 \\
\hline$\underline{\text { t ratio }>>}$ & $(-2.31)$ & $(-1.86)$ & $(-2.39)$ & $(2.48)$ & $(-4.98)$ & \\
\hline & & & & & & \\
\hline
\end{tabular}

Note: The bold figures represent significant correlation at $5 \%$ level.

It is observed from the table that NPA/D is positively correlated with proportions of banks in all ranges of CRAR levels with significant correlation results except the above 10 per cent range. Referring to Figure 1 it is verified that the trends of proportions of banks in all three ranges are downward sloping along with the trend of NPA/D. That means the adaptability of banks to newer CRAR ranges results into the falling NPA/D ratio. But there is negative and significant correlation of NPA/D with the proportions of banks in the above 10 per cent CRAR range which is also the usual outcome. Most of the banks in the said range have been the driving force of pulling down their NPA/D ratio.

Another side of the analysis is that there are negative and significant correlation coefficients of C-D ratio with all ranges of CRAR except the above 10 per cent CRAR like in the case of NPA/D ratio. As the proportions of banks in these three ranges of CRAR go down over time and the trend of C-D rise over time so it is natural to happen the negative correlations. But the sign of correlation of C-D ratio with the CRAR of above 10 per cent is positive and significant. This is also to happen. The correlation coefficient of NPA/D and C-D ratio, as a result, is negative and significant. Therefore, the shifting of banking capital from its unsecured to secured positions has been successful in the Indian banking context, although there are differences across the banks.

\section{Conclusion and Implications}

The study so far we have made has been framed in line with the examinations of the profiles of scheduled commercial banks in the suitability to the capital adequacy norms as well as to analyze the correlations among different banking instruments. It has been observed from our study over the period 1995-96 to 2009-10 that there has been variation across banks in following the guidelines of the reform committee. SBI group and foreign banks have been performing well in this respect. There has been rising trend of the proportions of banks in the above 10 per cent range of CRAR. The NPA-Deposit ratio and Credit-Deposit ratio have been observed to be positively and negatively correlated respectively for the first three ranges of CRAR and reverse in the above 10 per cent range. The correlation between the NPA-Deposit ratio and Credit-Deposit ratio is negative and significant. That means the banking system in India in respect of securitization of their assets is doing well in most of the banks, despite a few ones. The study in the present scenario is not complete under the ground that the falling NPA-Deposit ratio may not affect the Credit-Deposit ratio to rise. To ensure it causality tests could have been done and that can be the agenda for the future research. 


\section{References}

Basel Accord I and II for Banking Supervision (1988 and 2004). visit http://www.bis.org/bcbs/history.pdf

Bloem, A.M., \& Goerter, C.N (2001). The Macroeconomic Statistical Treatment of Non-Performing loans, Discussion Paper, Statistics Department of the IMF, December

Das, P.K \& P. Maiti (1998). Bank credit, output and bank deposits in West Bengal and selected states; Economic and Political Weekly, Nov, 21

Das, R \& K. Ray (2009). Economic Reforms and Allocation of Bank Credit: A Sector-wise Analysis of Selected

States; Banking Sector Reforms-A Fresh Outlook (edt); Mahamaya Publishing House, New Delhi.

Das, R (2010). Banking and Contemporary Issues (edt); Kunal Books, New Delhi

Goldsmith, Raymond W (1969). Financial Structure and Development . Yale University Press

Jain, V (2007). Non-performing Assets in Commercial Banks; published by Regal Publication, New Delhi

King, R. G and R. Levine (1993). Finance and Growth: Schumpeter Might Be Right. Quarterly Journal of Economics, $108(3)$

Marjit, S, P.K Das \& S. Chattopadhya (2003-04). Contemporary Macro Events of India: Some analytical discussion; Center for studies in social Sciences, Calcutta; published by Endowment Cell, RBI, Calcutta.

McGoven, J (1998). Why Bad Loans happen to Good Banks, The Journal of Commercial Lending, Philadelphia, Vol.78.

Misra, B S (2003). Allocative Efficiency of the Indian Banking System in the Post-Reform Period: A State Level Analysis; RBI Occasional Papers, Vol. 24, No. 3, winter

Mohan, R (2003). Transforming Indian Banking - In search of a better tomorrow, Reserve Bank of India Bulletin, January

Muniappam, G (2002). The NPA Overhang, Magnitude, Solutions and Legal reforms, Reserve Bank of India Rajeev, M. \& H. P. Mahesh (2010). Banking Sector Reforms and NPA: A study of Indian Commercial Banks, The Institute for Social and Economic Change Working Paper 252, Bangalore, India

Reddy, Y.V (2004). Credit Policy, Systems and Culture, RBI Bulletin, March

Report of the Committee on Banking Sector Reform, Chairman; M Narasimham, Reserve Bank of India, New Delhi, 1998

Report of the Committee on Financial System; Chairman; M Narasimham, Reserve Bank of India, New Delhi, 1991

Sarma, M \& Y. Nikaido (2007). India’s Capital Adequacy Regime, Economic and Political Weekly, Oct 27, Vol.

XLII, No. 43

Tirole, J (1988). The Theory of Industrial Organization, Cambridge, MIT Press 